\title{
Photosynthetic acclimation of beech seedlings to full sunlight following a major windstorm event in France
}

\author{
Phillip E. REYNOLDS ${ }^{\mathrm{a} *}$, Henri FROCHOT ${ }^{\mathrm{b}}$ \\ a NRCAN, Canadian Forest Service, 1219 Queen St. East, Sault Ste. Marie, Ontario, Canada P6A 2E5 \\ b Lerfob, UMR INRA-ENGREF, Growth and Yield Team, INRA Centre de Nancy, 54280 Champenoux, France
}

(Received 24 June 2002; accepted 3 August 2003)

\begin{abstract}
The effect of natural disturbance (windthrow of mature forests) on photosynthetic acclimation of shade-grown beech (Fagus sylvatica L.) seedlings was studied at a northeastern France location near Nancy in the Lorraine Region after a major windstorm event in December 1999. Treatments consisted of shaded and full sun plots prior to the storm, and plots where beech seedlings were released from shading by the storm. In 2000, beech in released and full sun plots were characterized by similar photosynthesis, transpiration, mesophyll conductance, and water use efficiencies, which were generally 2 -fold higher than those for beech in shaded plots. Additionally, photosynthetic saturation curves did not differ for released and full sun treatments, but did differ from the shade treatment. However, stomatal conductance values for shaded and released beech did not differ, and were lower than those for full sunlight seedlings. Acclimation continued in 2001, but remained incomplete, as evidenced by similar intrinsic water use efficiency values for released and shade treatments, which were lower than the mean value for the full sun treatment. Plant water potential remained highest for shaded seedlings in both years. These findings suggest that full acclimation is a gradual process, occurring over successive growing seasons. We speculate that full acclimation may be directly related to future development of greater root biomass in released seedlings.
\end{abstract}

beech / natural disturbance / photosynthetic acclimation / gas exchange / plant water potential

Résumé - Acclimatation photosynthétique de semis de hêtre à la pleine lumière après une tempête de grande amplitude en France. L'effet d'une perturbation naturelle (suppression du couvert forestier) sur l'acclimatation photosynthétique de jeunes hêtres (Fagus sylvatica L.) a été étudié dans le Nord-Est de la France après la tempête exceptionnelle de décembre 1999. Les modalités comportaient des plants ombragés (poussant sous couvert), ensoleillés (poussant en pleine lumière) et découverts (poussant sous couvert puis en pleine lumière après tempête). En 2000, les hêtres découverts et ensoleillés étaient caractérisés par des valeurs similaires de photosynthèse, transpiration, conductance du mésophille, et efficience de l'utilisation de l'eau, qui étaient en général deux fois plus fortes que celles des hêtres ombragés. En outre, les courbes de saturation photosynthétique ne différaient pas entre plants découverts et ensoleillés, mais différaient des plants ombragés. Cependant, les valeurs de conductance stomatique des hêtres ombragés et découverts ne différaient pas entre elles, et étaient plus basses que celles des hêtres ensoleillés. L'acclimatation continuait en 2001, mais restait incomplète, comme le montrent les valeurs similaires d'efficience de l'utilisation de l'eau intrinsèque pour les hêtres découverts et ombragés, qui étaient plus basses que les valeurs moyennes pour les hêtres ensoleillés. Le potentiel hydrique des plants restait le plus élevé pour les hêtres ombragés au cours des deux années. Ces résultats suggèrent que la pleine acclimatation est un processus graduel, se déroulant sur des saisons de croissance successives. Nous supposons qu'elle pourrait être directement reliée à une augmentation ultérieure de la biomasse racinaire des semis mis à découvert.

hêtre / perturbation naturelle / acclimatation photosynthétique / échanges gazeux / potentiel hydrique des plants

\section{INTRODUCTION}

In December 1999, a major windstorm event occurred across northern France, which resulted in the blowdown of mature beech forests, and the sudden release of understory shade-grown beech seedlings to full sunlight. The Lothar storm on December 26, crossed the Lorraine Region, and damaged the forests to an extent unknown in living memory. Damage was estimated to be about 30 million cubic meters of wood destroyed, eight times the average annual harvest. Shadegrown beech seedlings suddenly exposed to a full sunlight environment were hypothesized to show initial signs of trauma (possible morphological damage and physiological stress) prior to adapting to their new surroundings. The time required for injured seedlings to recover and to fully acclimate to their new environment was not known, and concerns arose about short-term survival and possible longer-term impacts on seedling growth and forest productivity. 
In mature beech stands of Europe, light levels in the understory are typically below $5 \%$ incident radiation $[5,14,15,21$, $37,38,52]$. Beech seedlings are able to persist for prolonged periods under these restricted light conditions [52], but respond favourably to canopy release with rapid increases in diameter and height growth [13, 14, 52]. Other studies have shown that beech seedlings growing under low light have reduced growth and are characterized by low diameter-height, root-shoot, and branch stem ratios [15, 37]. The morphology of beech seedlings is affected by the extent of canopy closure, and biomass allocation patterns differ depending upon the amount of light received [25, 37, 51]. Recently, the anatomical features of suppressed beech seedlings were shown to differ from those of released seedlings in forest gaps [15].

Limited information is available to accurately predict beech seedling physiological responses to a suddenly changed environment. All studies have been with potted seedlings under highly controlled (i.e., nursery, growth chamber, artificial irrigation and fertilization) conditions [10, 17, 30, 49, 50, 53, 54]. In addition, nearly all of these studies have been with leaves originated from sun leaf primordia formed prior to transfer to shaded environments. Only one study has involved the use of leaves derived from leaf primordia formed under specific light conditions $[53,54]$.

Nonetheless, Johnson et al. [30] observed that 1-yr old beech seedlings grown in pots in three distinct light environments: understory of mature beech forest, gaps within mature beech forests, and clearings, exhibited differing diurnal gas exchange patterns. Clearing seedlings had the highest rates of photosynthesis (NA), stomatal conductance (Gs), transpiration (E), and actual water use efficiency (WUE = NA/E), and understory seedlings had the lowest gas exchange rates. Gas exchange rates for gap seedlings were intermediate between those for clearing and understory seedlings for midday measurements. These results suggest that gas exchange rates are related to light availability, and that sufficient species plasticity exists for seedlings to adapt to distinctly differing light environments.

The potential for shade acclimated seedlings to respond to transfer to high irradiation was evaluated by Tognetti et al. [49] in an experiment where 1-yr old beech seedlings from the Abetone population were compared with those for 1-yr old seedlings derived from a Sicily population from southern Italy. Seeds from the northern Tuscany population (Abetone) were obtained from a more shaded environment than those from the Sicily population. Measurements of photosynthesis, fluorescence, and chlorophyll content were made on seedlings maintained in the high (HH) or low (LL) light environments, or those transferred from low light to high light (LH). Photosynthesis for $\mathrm{HH}$ seedlings was highest, and higher than for LL or LH seedlings. Photosynthesis was consistently lowest for the LL seedlings.

In the Tognetti et al. [49] study with 1-yr old seedlings, LH seedlings transferred to high light from low light conditions, never fully acclimated to $\mathrm{HH}$ photosynthesis levels over the 20-days measurement period. Declining fluorescence was taken as evidence of photoinhibition, and correlated with specific leaf damage in chamber grown plants. In another experiment with 3 -yr old beech seedlings derived from seeds collected from beech trees near Capracotta, Italy (central Italy), Tognetti et al. [50] obtained distinctly differing results from their later study with 1-yr old seedlings. In this earlier study [50], seedlings were prepared in a similar manner, but post-transfer measurements of shaded seedlings transferred to high light irradiance revealed full and rapid acclimation of NA values approaching those for full light controls. An increase in photosynthetic rates for transferred seedlings began 8 days after transfer, and was nearly complete after 1 month. They attributed this difference to a lack of damage for measured leaves. Unlike their later experiment, leaves used for photosynthesis measurements were further down into the seedling canopy (more shaded), and did not sustain the damage readily observed for leaves sampled from the upper canopies of 1-yr old seedlings.

The time for acclimation of field- and shade-grown seedlings to full sunlight remains unknown, and no other concurrent studies reporting on gas exchange properties of fieldgrown beech seedlings acclimated to full sun or shade, or of those released from shade into full sun are known to exist.

To date, most studies of morphological or physiological differences of shaded or full sun foliage have been with commercially valuable coniferous species [1, 31, 39]. Studies of seedlings released from shade to full sun are rare [11]. In 1999, Mohammed and Parker [39] reported that shade-grown potted hemlock seedlings transferred to full sunlight had intermediate net photosynthesis (NA) and mesophyll conductance (Gm) compared to sun and shade plants. Higher stomatal conductance $(\mathrm{Gs})$ and $\mathrm{Ci} / \mathrm{Ca}$ (ratio of intercellular to ambient $\mathrm{CO}_{2}$ ) levels were observed in transferred hemlock seedlings relative to sun-grown plants. Sun-grown hemlock foliage also had higher light saturated net photosynthesis than shade-grown foliage. Measurements were made 26 days after transfer, and not continued thereafter. They concluded that shade-formed foliage of hemlock possessed a limited capacity for photosynthetic acclimation to high light, as evidenced by its inability to achieve light saturated rates of gas exchange equivalent to that for sun foliage, and also a restricted photoprotective capability iniatially following exposure, as evidenced by a decline in relative fluorescence. They further speculated that development of photosynthetic competence over successive foliar cycles $[20,47]$ is a possibility that warrants further investigations. Early foliage produced after transfer may be of a transitional form and function, as evidenced by intermediate gas exchange. Full acclimation may involve both structural and functional changes in foliage and may be facilitated by the production of new leaves [42].

Information to date suggests that acclimation to a high light environment is species dependent, and likely related to the successional stage the species occupies [9]. Shade-intolerant, pioneer species may be less adversely affected by sudden exposure to full sunlight than shade-tolerant, climax species such as hemlock or beech [8]. Additionally, spruces and pines may be less impacted than conifers such as hemlock [27, 34, 55]. Presumably, a similar phenomena exists for hardwoods. Deciduous species have faster growth rates with higher leaf turnover, which facilitates structural or functional changes needed to adapt to a high light environment [27]. By contrast, conifers retain their foliage for a longer period of time, and must rely more heavily on functional (physiological) changes 
to cope with a rapidly changed environment. For this reason, deciduous species are generally regarded as having higher plasticity and acclimation potential [8, 28, 42].

Objectives of this study were to quantify photosynthetic responses of field- and shade-grown beech seedlings to sudden exposure to full sunlight and to chronicle any recovery of these seedlings over time.

\section{MATERIALS AND METHODS}

The effect of natural disturbance (windthrow of mature forests) on photosynthetic acclimation of shade-grown, and formally fieldgrown understory, beech (Fagus sylvatica L.) seedlings was studied at a northeastern France location. The approximate 10 ha site (foret Domaniale de Haye, parcelle 434) is located in the Lorraine Region, near Nancy. The site was chosen because of the presence of a number of pre-existing research treatments $[14,41]$. These included clearcut and shelterwood plots and cylindrical shade houses $(1 \mathrm{~m}$ diameter $\times$ $2 \mathrm{~m}$ height each) with planted beech seedlings [41] and shelterwood plots with naturally-regenerated beech seedlings [14]. During the storm, most mature overstory beech trees were blown down in some plots, affording an unprecedented opportunity to compare disturbed plots with other undisturbed plots.

Prior to the December 1999 windstorm, mature overstory beech trees ranged in age from 140 to 180 years, and were approximately 25 to $30 \mathrm{~m}$ in height $[14,15]$. Understory beech seedlings were quite small at the time of the storm and thereafter. Most planted beech seedlings were $<2 \mathrm{~m}$ height in 2000, and averaged approximately $1 \mathrm{~m}$ in height in 2000. In 1998, planted seedlings in shade houses and those in clearcut and shelterwood plots, averaged between 0.5 to $0.6 \mathrm{~m}$ height [24]. Seedlings were planted at a density of 1600/ha in 1996, or one seedling per shade house. Naturally-regenerated seedlings were generally much smaller than planted seedlings in 2000, and generally $<1 \mathrm{~m}$ height in 2000. In 1999, most were observed to be $<0.3 \mathrm{~m}$ in height $[14,15]$. Seedling heights tended to be correlated with overstory basal area, and were greatest where basal area was least, and least where basal area was greatest. Prior to the December 1999 windstorm event, relative light intensity $(\%)$ near the forest floor, ranged from 5 to $52 \%$ in naturally-regenerated shelterwoods $[14,15]$. Most naturally-regenerated seedlings were < 20 years age in 1999 .

Vegetative cover on the forest floor was slight or even sparse for most shelterwoods, prior to and after the storm, especially where overstory basal area was highest prior to the storm. Cover increased most in these shelterwoods after the storm, where overstory basal area had been least prior to the storm. However, in no instance did competing vegetation overtop beech seedlings, even during the second post-storm growing season (2001). Release of naturally-regenerated beech seedlings sometimes resulted in a rapid growth spurt from 2000 to 2001, where pre-storm overstory basal area was low. By contrast, where pre-storm overstory basal area was higher, rapid growth from 2000 to 2001 was not observed. Where overstory basal area was highest prior to the storm, naturally-regenerated seedlings appeared to remain stunted in their growth even during the second (2001) poststorm growing season. Vegetative growth in clearcut plots was variable, consisting of bare soil, grass plots, and blackberry plots [24, 41] Grass and blackberry cover tended to increase in height through 2001, but in nearly all instances did not overtop the planted beech seedlings.

The site is situated on a limestone plateau overlooking the Moselle River. The site is characterized by shallow (approximately $40 \mathrm{~cm}$ ), rocky, brown calcareous soils, with limited water holding capacity. Soil conditions varied within the study area, and ranged between rendosol and calcisol types $[6,14,15]$. Maximum extractable soil water
(MEW) ranged between $58 \mathrm{~mm}$ for the rendosol type and $68 \mathrm{~mm}$ for the calcisol type [7,14]. Annual precipitation is approximately $750 \mathrm{~mm}$ and the mean annual temperature is approximately $12^{\circ} \mathrm{C}$ [24].

Post-storm differences among these plots were examined by grouping the plots into three categories: shade plots, released plots, and full sun plots. Prior to the storm, available light in shelterwood plots averaged approximately $25 \%$. Released plots were converted to $100 \%$ available light after the December 1999 windstorm. Shelterwood plots were grouped into shade or released plots, and compared with full sun, clearcut plots (historically $100 \%$ available light). Using this approach, shade, released, and full sun plots consisted of the following types of plots. Shade plots ( $\mathrm{N}=5$, approximately $25 \%$ available light) consist of: (1) undisturbed shelterwoods with planted understory seedlings (approximately 33\% available light), (2) undisturbed shelterwoods with naturally-regenerated understory seedlings (approximately 5 to 37\% available light), and (3) shade houses with planted seedlings (approximately $33 \%$ available light). Released plots $(\mathrm{N}=6$, currently $100 \%$ available light) consist of: (1) windthrown shelterwoods with planted understory seedlings (formerly 33\% available light) and (2) windthrown shelterwoods with naturally-regenerated understory seedlings (formerly 5 to $37 \%$ available light). Full sun plots $(\mathrm{N}=6$, historically $100 \%$ available light $)$ consist of clearcut plots with planted seedlings (100\% available light). Five to 15 representative beech seedlings were randomly selected and tagged throughout each treatment plot. A total of 267 seedlings were measured: $\mathrm{N}=91$ shade, 86 released, and 90 full sun. Treatment differences for shade, released, and full sun plots were analyzed by analysis of variance (ANOVA), using a replicated plot design, according to Snedecor and Cochran [48].

Seedling water potential and gas exchange were assessed over two growing seasons (2000 and 2001) following a major windstorm event in December 1999 that resulted in the blowdown of mature beech forests across northern France. Measurements occurred on August 1, 4, 7, 8, 9 of 2000 and again on September 18, 19, 21, 22, 24, 25 of 2001. Results presented here are pooled for each of the measurement dates.

Photosynthesis $(\mathrm{NA}=$ net assimilation), stomatal conductance (Gs), transpiration (E), internal $\mathrm{CO}_{2}$ (CINT), and other environmental parameters for tagged beech (upper crown, new leaves) were measured using a Li-Cor LI-6200 portable photosynthesis unit (Li-Cor Inc., Lincoln, NB). Concurrently, midday water potentials for beech shoots were measured. Measurements occurred between 1000 and $1700 \mathrm{~h}$ daily, and were stratified and replicated among the various treatment plots throughout each day to preclude biasing the results.

Water use efficiencies (WUE) were calculated using the formulas: AWUE $=$ NA/E [33] and IWUE $=$ NA/Gs [22]. Mesophyll conductance was calculated using the formula $\mathrm{Gm}=\mathrm{NA} / \mathrm{CINT}$ [35]. The ratio of intercellular to ambient $\mathrm{CO}_{2}(\mathrm{Ci} / \mathrm{Ca})$ was examined as described by Mohammed and Parker [39] and earlier by Farquhar et al. [23].

Photosynthesis values and concurrent measurements of photosynthetically-active radiation (PAR) were further used to develop light saturation curves based upon the hyperbolic function: NA saturation = $\mathrm{ax} / \mathrm{b}+\mathrm{x}$, where $\mathrm{x}=$ PAR [12]. Differences among the various treatment (i.e., shade, released, full sun) curves were analyzed by analysis of covariance (ANCOVA), using a replicated plot design, with PAR as the covariate.

\section{RESULTS}

Environmental parameters remained steady during gas exchange and midday water potential measurements in both years (2000 and 2001), and parameters generally did not differ among the three treatments (Tab. I). Relative humidity was 
Table I. Mean environmental conditions during gas exchange measurements during first (2000) and second (2001) growing seasons after December 1999 windstorm event. Values are means. Values are based upon a replicated plot design. Numbers within rows followed by the same letter are not significantly different at the $10 \%$ level according to Tukey's Test. Standard error of mean (SEM) values are shown in parentheses following each mean value.

\begin{tabular}{lcccc}
\hline Variable & Year & Shade $^{1}$ & Released $^{2}$ & Full Sun $^{3}$ \\
\hline \# of plots & 2000 & 5 & 6 & 6 \\
& 2001 & 5 & 6 & 6 \\
Air temperature & 2000 & $24.3 \mathrm{~b}$ & $26.8 \mathrm{a}$ & $24.5 \mathrm{~b}$ \\
& & $(0.5)$ & $(0.3)$ & $(0.2)$ \\
& 2001 & $19.6 \mathrm{a}$ & $21.0 \mathrm{a}$ & $21.2 \mathrm{a}$ \\
& & $(0.4)$ & $(0.5)$ & $(0.8)$ \\
Relative humidity & 2000 & $50.7 \mathrm{a}$ & $51.9 \mathrm{a}$ & $53.9 \mathrm{a}$ \\
& & $(1.6)$ & $(1.6)$ & $(0.9)$ \\
& 2001 & $52.2 \mathrm{a}$ & $56.6 \mathrm{a}$ & $52.5 \mathrm{a}$ \\
& & $(1.3)$ & $(1.2)$ & $(2.8)$ \\
Vapor pressure deficit & 2000 & $\begin{array}{c}15.1 \mathrm{a} \\
(0.8)\end{array}$ & $\begin{array}{c}17.2 \mathrm{a} \\
(1.0)\end{array}$ & $\begin{array}{c}15.0 \mathrm{a} \\
(0.4)\end{array}$ \\
& & $(0.9 \mathrm{a}$ & $10.9 \mathrm{a}$ & $12.2 \mathrm{a}$ \\
& 2001 & $10.9 \mathrm{a})$ & $(1.2)$ \\
\hline
\end{tabular}

1 Shade plots consist of: (1) undisturbed shelterwoods with planted understory seedlings, (2) undisturbed shelterwoods with naturally-regenerated understory seedlings, and (3) shade houses with planted seedlings.

2 Released plots consist of: (1) windthrown shelterwoods with planted understory seedlings and (2) windthrown shelterwoods with naturallyregenerated understory seedlings.

${ }^{3}$ Full sun plots consist of clearcut plots with planted seedlings.

Air temperature $={ }^{\circ} \mathrm{C}$, relative humidity $(\mathrm{RH})=\%$, vapour pressure deficit $(\mathrm{VPD})=\mathrm{kPa}$.

roughly $50 \%$ in both years. Slightly lower vapour pressure deficits (VPD) were observed in 2001 during fall measurements than in 2000 during late summer measurements. Nonetheless, VPD values in both years remained well below air temperatures, and seedlings were clearly not stressed during measurements. No air temperature differences were observed among treatments in 2001 when cooler fall temperatures prevailed. Air temperature was only slightly higher for released seedlings in 2000 when summer air temperatures were generally higher than during fall measurements.

In both years, midday water potential was lowest for released seedlings (Tab. II). In 2000, released and full sun treatments were characterized by similar PAR, photosynthesis, transpiration, water use efficiencies, and mesophyll conductance values, which were significantly higher than those for the shade treatment. Net assimilation (NA), AWUE, IWUE, and Gm were generally 2-fold higher for released and full sun treatments than for the shade treatment. By contrast, stomatal conductance $(\mathrm{Gs})$ values for shade $\left(0.496 \mathrm{~mol} \cdot \mathrm{m}^{-2} \cdot \mathrm{s}^{-1}\right)$ and released (0.469) treatments remained similar, and lower than that for the full sun (0.845) treatment.

No differences for Gs or AWUE were observed in 2001 for shade, released, and full sun treatments (Tab. II). However,
Table II. Mean treatment differences for shelterwood and clearcut treatments during first (2000) and second (2001) growing seasons after December 1999 windstorm event. Values are means. Values are based upon a replicated plot design. Numbers within rows followed by the same letter are not significantly different at the $10 \%$ level according to Tukey's Test. Standard error of mean (SEM) values are shown in parentheses following each mean value.

\begin{tabular}{|c|c|c|c|c|}
\hline Variable & Year & Shade $^{1}$ & Released $^{2}$ & Full Sun ${ }^{3}$ \\
\hline \multirow[t]{2}{*}{ \# of plots } & 2000 & 5 & 6 & 6 \\
\hline & 2001 & 5 & 6 & 6 \\
\hline \multirow[t]{2}{*}{ PAR } & 2000 & $\begin{array}{c}137 \mathrm{~b} \\
(54)\end{array}$ & $\begin{array}{c}873 a \\
(73)\end{array}$ & $\begin{array}{c}832 \mathrm{a} \\
(73)\end{array}$ \\
\hline & 2001 & $\begin{array}{c}234 \mathrm{c} \\
(83)\end{array}$ & $\begin{array}{l}827 \mathrm{~b} \\
(91)\end{array}$ & $\begin{array}{l}1346 \mathrm{a} \\
(110)\end{array}$ \\
\hline \multirow[t]{2}{*}{ MWP } & 2000 & $\begin{array}{l}-2.09 \mathrm{a} \\
(0.15)\end{array}$ & $\begin{array}{l}-2.73 \mathrm{~b} \\
(0.20)\end{array}$ & $\begin{array}{c}-2.82 \mathrm{~b} \\
(0.04)\end{array}$ \\
\hline & 2001 & $\begin{array}{c}-1.87 \mathrm{a} \\
(0.23)\end{array}$ & $\begin{array}{l}-2.58 \mathrm{~b} \\
(0.11)\end{array}$ & $\begin{array}{c}-2.12 \mathrm{ab} \\
(0.20)\end{array}$ \\
\hline \multirow[t]{2}{*}{ NA } & 2000 & $\begin{array}{l}2.41 \mathrm{~b} \\
(0.94)\end{array}$ & $\begin{array}{l}7.83 \mathrm{a} \\
(1.46)\end{array}$ & $\begin{array}{l}6.68 \mathrm{a} \\
(1.10)\end{array}$ \\
\hline & 2001 & $\begin{array}{l}4.09 \mathrm{~b} \\
(1.09)\end{array}$ & $\begin{array}{c}6.24 \mathrm{ab} \\
(0.98)\end{array}$ & $\begin{array}{l}8.58 \mathrm{a} \\
(0.70)\end{array}$ \\
\hline \multirow[t]{2}{*}{ Gs } & 2000 & $\begin{array}{l}0.496 \mathrm{~b} \\
(0.040)\end{array}$ & $\begin{array}{l}0.469 \mathrm{~b} \\
(0.041)\end{array}$ & $\begin{array}{l}0.845 \mathrm{a} \\
(0.123)\end{array}$ \\
\hline & 2001 & $\begin{array}{l}0.365 \mathrm{a} \\
(0.078)\end{array}$ & $\begin{array}{l}0.602 \mathrm{a} \\
(0.069)\end{array}$ & $\begin{array}{l}0.542 \mathrm{a} \\
(0.111)\end{array}$ \\
\hline \multirow[t]{2}{*}{ E } & 2000 & $\begin{array}{l}5.05 \mathrm{~b} \\
(0.17)\end{array}$ & $\begin{array}{l}5.83 \mathrm{a} \\
(0.10)\end{array}$ & $\begin{array}{l}5.68 \mathrm{a} \\
(0.08)\end{array}$ \\
\hline & 2001 & $\begin{array}{l}2.88 \mathrm{~b} \\
(0.34)\end{array}$ & $\begin{array}{l}4.24 \mathrm{a} \\
(0.13)\end{array}$ & $\begin{array}{l}4.68 \mathrm{a} \\
(0.37)\end{array}$ \\
\hline \multirow[t]{2}{*}{ AWUE } & 2000 & $\begin{array}{l}0.45 \mathrm{~b} \\
(0.16)\end{array}$ & $\begin{array}{l}1.33 \mathrm{a} \\
(0.24)\end{array}$ & $\begin{array}{l}1.17 \mathrm{a} \\
(0.19)\end{array}$ \\
\hline & 2001 & $\begin{array}{l}1.32 \mathrm{a} \\
(0.20)\end{array}$ & $\begin{array}{l}1.42 \mathrm{a} \\
(0.19)\end{array}$ & $\begin{array}{l}1.86 \mathrm{a} \\
(0.12)\end{array}$ \\
\hline \multirow[t]{2}{*}{ IWUE } & 2000 & $\begin{array}{l}5.03 \mathrm{~b} \\
(1.96)\end{array}$ & $\begin{array}{l}17.06 \mathrm{a} \\
(2.67)\end{array}$ & $\begin{array}{l}12.61 \mathrm{a} \\
(1.95)\end{array}$ \\
\hline & 2001 & $\begin{array}{c}11.56 \mathrm{~b} \\
(2.25)\end{array}$ & $\begin{array}{c}11.34 \mathrm{~b} \\
(1.46)\end{array}$ & $\begin{array}{l}20.06 \mathrm{a} \\
(3.53)\end{array}$ \\
\hline \multirow[t]{2}{*}{$\mathrm{Gm}$} & 2000 & $\begin{array}{l}7.58 \mathrm{~b} \\
(3.10)\end{array}$ & $\begin{array}{l}26.05 \mathrm{a} \\
(5.09)\end{array}$ & $\begin{array}{c}22.18 \mathrm{a} \\
(3.93)\end{array}$ \\
\hline & 2001 & $\begin{array}{l}12.54 \mathrm{~b} \\
(3.47)\end{array}$ & $\begin{array}{c}19.21 \mathrm{ab} \\
(3.12)\end{array}$ & $\begin{array}{l}26.95 \mathrm{a} \\
(2.42)\end{array}$ \\
\hline \multirow[t]{2}{*}{ CINT } & 2000 & $\begin{array}{c}335.5 \mathrm{a} \\
(6.0)\end{array}$ & $\begin{array}{c}309.0 \mathrm{~b} \\
(5.0)\end{array}$ & $\begin{array}{c}311.2 \mathrm{~b} \\
(4.8)\end{array}$ \\
\hline & 2001 & $\begin{array}{c}332.8 \mathrm{a} \\
(4.7)\end{array}$ & $\begin{array}{c}328.4 \mathrm{a} \\
(3.3)\end{array}$ & $\begin{array}{c}321.4 \mathrm{a} \\
(7.8)\end{array}$ \\
\hline \multirow[t]{2}{*}{$\mathrm{CO}_{2}$} & 2000 & $\begin{array}{c}354.2 \mathrm{a} \\
(2.3)\end{array}$ & $\begin{array}{c}354.1 \mathrm{a} \\
(2.0)\end{array}$ & $\begin{array}{c}346.8 \mathrm{~b} \\
(1.2)\end{array}$ \\
\hline & 2001 & $\begin{array}{c}361.8 \mathrm{~b} \\
(1.2)\end{array}$ & $\begin{array}{c}360.0 \mathrm{~b} \\
(1.7)\end{array}$ & $\begin{array}{c}370.5 \mathrm{a} \\
(3.0)\end{array}$ \\
\hline \multirow[t]{2}{*}{$\mathrm{Ci} / \mathrm{Ca}$} & 2000 & $\begin{array}{l}0.95 \mathrm{a} \\
(0.01)\end{array}$ & $\begin{array}{l}0.87 \mathrm{~b} \\
(0.02)\end{array}$ & $\begin{array}{l}0.90 \mathrm{~b} \\
(0.01)\end{array}$ \\
\hline & 2001 & $\begin{array}{l}0.92 \mathrm{a} \\
(0.01)\end{array}$ & $\begin{array}{l}0.91 \mathrm{a} \\
(0.01)\end{array}$ & $\begin{array}{l}0.87 \mathrm{~b} \\
(0.02)\end{array}$ \\
\hline
\end{tabular}

${ }^{1}$ Shade plots consist of: (1) undisturbed shelterwoods with planted understory seedlings, (2) undisturbed shelterwoods with naturally-regenerated understory seedlings, and (3) shade houses with planted seedlings.

2 Released plots consist of: (1) windthrown shelterwoods with planted understory seedlings and (2) windthrown shelterwoods with naturallyregenerated understory seedlings.

${ }^{3}$ Full sun plots consist of clearcut plots with planted seedlings.

$\mathrm{PAR}=\mu \mathrm{mol} \cdot \mathrm{s}^{-1} \cdot \mathrm{m}^{-2}, \mathrm{MWP}=\mathrm{MPa}, \mathrm{NA}=\mu \mathrm{mol} \cdot \mathrm{m}^{-2} \cdot \mathrm{s}^{-1}, \mathrm{Gs}=\mathrm{mol} \cdot \mathrm{m}^{-2} \cdot \mathrm{s}^{-1}$, $\mathrm{E}=\mathrm{mmol} \cdot \mathrm{m}^{-2} \cdot \mathrm{s}^{-1}$, AWUE and IWUE $=\mu \mathrm{mol} \mathrm{CO} 2 \cdot \mathrm{mmol}^{-1} \mathrm{H}_{2} \mathrm{O}, \mathrm{Gm}=$ $\mu \mathrm{mol} \mathrm{CO} 2 \cdot \mathrm{m}^{-2} \cdot \mathrm{s}^{-1}$. 


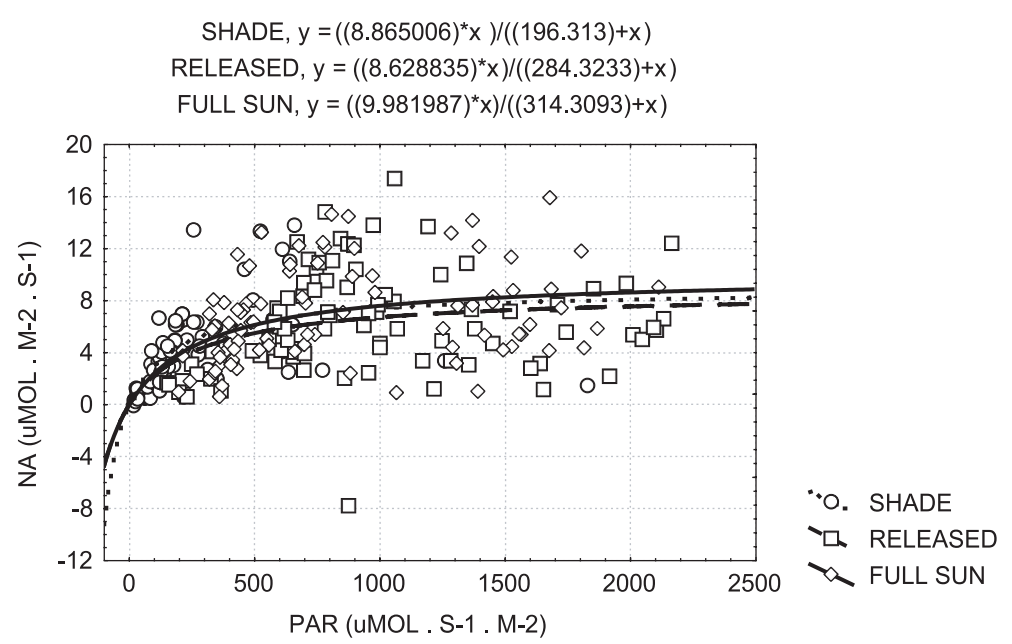

Figure 1. Photosynthetic saturation curves for shelterwood and clearcut treatments during the first (2000) growing season after December 1999 windstorm event. Shade plots (approximately 25\% available light) consist of: (1) undisturbed shelterwoods with planted understory seedlings (approximately 33\% available light), (2) undisturbed shelterwoods with naturally-regenerated understory seedlings (approximately 5 to $37 \%$ available light), and (3) shade houses with planted seedlings (approximately 33\% available light). Released plots (currently $100 \%$ available light) consist of: (1) windthrown shelterwoods with planted understory seedlings (formerly $33 \%$ available light) and (2) windthrown shelterwoods with naturally-regenerated understory seedlings (formerly 5 to $37 \%$ available light). Full sun plots (historically $100 \%$ available light) consist of clearcut plots with planted seedlings (100\% available light). A total of 267 seedlings were measured: $N=91$ shade, 86 released, and 90 full sun. Mean photosynthesis (NA) values are: 3.82 shade, $\mathrm{SEM}=0.31 ; 6.28$ released, SEM =0.43; and 6.68 full sun, SEM =0.38. Mean photosynthetically-active radiation (PAR) values are: 229 shade, $\mathrm{SEM}=28 ; 979$ released, $\mathrm{SEM}=55$; and 832 full sun, $\mathrm{SEM}=53$. Mean NA and PAR values for released and full sun seedlings differ from shade seedlings, but do not differ from each other.

IWUE (= NA/Gs) values for shade $\left(11.56 \mu \mathrm{mol} \mathrm{CO} 2 \cdot \mathrm{mmol}^{-1}\right.$ $\mathrm{H}_{2} \mathrm{O}$ ) and released (11.34) treatments remained similar, and lower than that for the full sun (20.06) treatment. Transpiration $(\mathrm{E})$ and $\mathrm{Gm}$ values remained similar for released and full sun treatments, and higher (E) than for the shade treatment.

In August 2000, photosynthetic saturation values (a) varied for shade $\left(8.86 \mu \mathrm{mol} \cdot \mathrm{m}^{-2} \cdot \mathrm{s}^{-1}\right)$, released (8.63), and full sun (9.98) treatments consisting of former shelterwood plots (Fig. 1). Statistical differences for these relationships (curves) were evaluated by analysis of covariance (ANCOVA) using PAR as the covariate. Mean photosynthesis (NA) values for released $\left(6.28 \mu \mathrm{mol} \cdot \mathrm{m}^{-2} \cdot \mathrm{s}^{-1}\right)$ and full sun (6.68) seedlings differed from shade (3.82) seedlings, but did not differ from each other. Mean PAR values (ANOVA) for released $\left(979 \mu \mathrm{mol} \cdot \mathrm{s}^{-1} \cdot \mathrm{m}^{-2}\right)$ and full sun (832) seedlings differed from shade (229) seedlings, but did not differ from each other.

\section{DISCUSSION}

Although released seedlings had begun to acclimate to full light conditions by late summer of 2000 , the process remained incomplete, as evidenced by similar stomatal conductance (Gs) values for released and shade treatments. Acclimation continued in 2001, but also remained incomplete, as evidenced by similar intrinsic water use (IWUE $=\mathrm{NA} / \mathrm{Gs}$ ) values for released and shade treatments. These findings suggest that full acclimation is a gradual process, occurring over successive growing seasons. Mohammed and Parker [39] and others [19, $20,47]$, working with both coniferous and deciduous species, have also concluded that full acclimation is a gradual process.

The continued acclimation of beech seedlings during the second growing season (2001) after release suggests a few structural (morphological) modifications needed before full acclimation is attainable. One modification might involve the numbers of stomates on the leaf surface. During the first growing season (2000) after release, there may have been fewer stomates on the leaf surface of shade-grown and released seedlings compared with sun-grown seedlings. Evidence for this hypothesis is found in the recent (2001) work of Aranda et al. [3]. They observed that planted beech seedlings growing in the understory of a thinned pine stand had higher stomatal densities during the second year after thinning. Other leaf morphological, anatomical, and structural changes, were correlated with enhanced light exposure, and were observed over time. These included an increase in specific leaf mass (SLM) during both years, an increase in total blade thickness during the first growing season, and an increase in the thickness of palisade parenchyma (PP) during the second growing season.

Another structural (morphological) modification might have involved an increase in beech seedling root biomass over time. Following the December 1999 windstorm, released and shade-grown beech seedlings probably had less root mass, 
particularly fine root biomass, than seedlings continuously grown in full sun. Several studies have documented that beech seedlings growing under low light availability have reduced growth and are characterized by low diameter-height, rootshoot, and branch-stem ratios [15, 37]. The morphology of seedlings is altered by the extent of canopy closure, resulting in differing biomass allocation patterns that are dependent upon light availability [14, 25, 37, 51]. Shaded seedlings possess less root biomass than those grown in full sun. Consequently, their hydraulic capabilities to transport water are less developed, and more restricted, than larger root systems of larger sun grown seedlings. Recently released seedlings would be expected to have small root mass, and restricted in their hydraulic capabilities to transport water. For these released seedlings, suddenly exposed to full sunlight and higher temperatures [4], their existing root hydraulic capabilities would likely be insufficient to keep pace with higher transpirational demand, resulting in notable plant water stress. To conserve water, released seedlings would close their stomates [36], resulting in decreased stomatal conductance. In this study, released seedlings exhibited the greatest water stress, and stomatal conductance for these seedlings was low, and did not differ from shaded seedlings. Released seedlings could compensate for this greater transpirational demand by initially allocating greater resources to developing a larger root mass, thereby allowing them to gradually acclimate to their new full sun environment. Future studies to verify this hypothesis would be worthwhile.

Further support for this hypothesis comes from the recent work (2002) of Kneeshaw et al. [32]. They observed biomass allocation in understory conifer seedlings (advance regeneration) for 6 years after their release from overstory conifers using partial cutting. Following the sudden opening of the overstory on relatively dry sites, seedlings first responded with an immediate increase in root growth. Increases in shoot growth were delayed by one year. Increases in branch and leader growth were further delayed by two and three years. They concluded that seedlings allocate greater initial resources to root growth to offset increased transpiration losses associated with greater light and temperature conditions.

In this study, midday water potential remained below $-1.5 \mathrm{MPa}$ for all beech seedlings, affirming that these seedlings sustained a certain degree of water stress [36]. Unlike other studies, our beech seedlings were all grown in the wild, receiving irregular rainfall. Beech seedlings studied by others [30, $49,50,53]$ were potted, irrigated on a regular basis, and fertilized - all factors favoring high water potential, gas exchange, conductance, net photosynthesis, and growth. In the wild, seedlings subjected to variable environmental gradients, and hense variable water availability, generally exhibit variable water stress, gas exchange, nutrient uptake, and growth [44]. In turn, water stress generally results in nutrient stress [40, 43], both factors in addition to light, limiting seedling survival, recovery, and growth. Most frequently, seedlings that are water stressed (i.e., midday water potential below $-1.5 \mathrm{MPa}$ ), also exhibit lower stomatal conductance, gas exchange, nutrient uptake, and growth [44].

Drought conditions could be expected to have a significant impact on the speed of seedling recovery and complete acclimation to the new environment. Coutts [16] observed that suf- ficient development of root sinks for photosynthate are an important pre-requisite for light acclimation. Under conditions of drought, development of root biomass is inhibited, and acclimation retarded. Transpiration would be inhibited and plants would close stomates to conserve water [36]. Additional fine roots could compensate for droughty conditions, allowing stomates to be open for longer periods of time daily. Extending the period of higher plant water potential when stomates remain open is crucial to maximizing active periods of photosynthesis [45].

Similarly, available leaf area is drought dependent [46]. All species depend upon new leaf production to attain full expression of their acclimation potential [42]. However, continuous foliar production is dependent upon favorable site conditions in the new environment, which are promoting of new growth [29]. Under conditions of drought, formation of new leaves could be curtailed under extreme drought conditions or delayed under more moderate drought conditions, resulting in variable delays in the time to achieve full acclimation.

Stomatal conductance is also affected by light availability [49], in addition to drought effects. Normally, conductance increases under full light conditions, also partly accounting for lower observed stomatal conductance values, for shaded beech seedlings, in this field study. In this study, shaded beech seedlings were characterized by the lowest mean stomatal conductance values, and also by the highest mean midday leaf water potential values. The later observation is in close agreement with results reported by Cochard et al. [17]. They observed that midday leaf water potential and xylem water potential values were higher for shaded branches $(-1.39$ and $-0.64 \mathrm{MPa}$, respectively) than those for sun-exposed branches $(-2.37$ and $-1.12 \mathrm{MPa}$, respectively) of mature beech trees. Under shaded conditions, lower gas exhange rates (Gs, E, NA), higher ambient and internal $\mathrm{CO}_{2}$ levels, and higher respiration rates prevail $[42,49]$. Opportunities for net photosynthetic gain are often restricted to random and intermittent periods of sunlight (sunflecks) reaching the forest floor via canopy gaps.

By contrast to structural (morphological) changes, other functional (physiological) changes appear to have occurred rapidly during the first (2000) growing season of this study. This finding is similar to that observed by Tognetti et al. [50] for 3-yr old potted beech seedlings, where an increase in photosynthetic rates for well-watered, shade-acclimated seedlings transferred to high irradiance, began 8 days after transfer, and was nearly complete after 1 month. For water-stressed beech seedlings, this was not the case. At 30 days, NA was significantly lower in rewatered plants (i.e., rewatering began at 9 days when PWP had dropped to $-2.0 \mathrm{MPa}$ ) than in control plants (i.e., well-watered) in both light treatments. The later affirms, as discussed above, that field water stress can and does impede the speed of recovery and full acclimation, of shade-acclimated beech seedlings transferred to full irradiation. In this study, full photosynthetic acclimation may have been delayed beyond 30 days, because all seedlings were water-stressed. Full photosynthetic acclimation was probably able to occur sooner for the 3-yr old potted beech seedlings studied by Tognetti et al. [50], since well-watered seedlings were not water-stressed, and all seedlings probably had similar root biomass. 
In this study, both released and sun-grown beech seedlings were characterized by similar photosynthesis, transpiration, water use efficiency (AWUE and IWUE), and mesophyll conductance values in August 2000 which did not differ, and which were often 2-fold higher than those for shaded beech seedlings. No differences in light saturated curves for photosynthesis were observed for released and sun-grown beech seedlings, but saturation curves for both differed from the light saturation curve for shaded seedlings. Concurrently, internal $\mathrm{CO}_{2}$ was similar for released and sun-grown seedlings, suggesting that both released and sun-grown seedlings probably had similar palisade mesophyll characteristics. This finding is consistent with similar mesophyll conductance $(\mathrm{Gm})$ rates, and is consistent with findings of Mohammed and Parker [39]. They reported no difference in palisade mesophyll characteristics for transferred and sun plants. These findings are all consistent with rapid acclimation of released seedlings to a fullsun environment.

Our findings also agree with those observed by Welander and Ottosson [53]. They observed higher leaf transpiration (E) rates for beech seedlings transferred to higher light environments from previous year (growing period) environments where lower light levels prevailed. The similarity of these results to ours, is especially noteworthy, since it is the only potted beech study where leaves were derived from leaf primordia differentiated under specific light environments, including shaded environments. All other studies with potted beech have involved seedling leaves originated from sun leaf primordia formed prior to transfer to shaded environments. In the present study, seedling leaves for shaded and released seedlings originated from shade leaf primordia, formed in fieldgrown seedlings, prior to release of shaded seedlings to full irradiation. Tognetti et al. [50] have recognized the possible limitations of applying prior results (i.e., studies with beech leaves originating from sun leaf primordia) to field scenarios where leaves originated from shade leaf primordia, stating that "more definite results could be attained by studying the acclimation response of plants grown in shade over the long term". Inherent in this statement, is also the need to study field grown seedlings versus those in pots, transferred to field scenarios.

In our field study, earlier signs of a lag in acclimation may have been missed because of the timing of our initial gas exchange and leaf water potential measurements in August 2000 , the fourth month after leaf emergence. By late summer 2000 , no significant difference between light saturation curves was observed for released and full sun seedlings, confirming that photosynthetic acclimation was complete, and that photoinhibition probably no longer existed. The results of Tognetti et al. [50], suggest that nearly complete acclimation can occur as early as 30 days after transfer from shade to high irradiance. Assuming this to be correct, we would have likely missed any evidence of gradual acclimation or even possible indications of photoinhibition by delaying our first measurements until August. Possible indications of incomplete photosynthetic acclimation or possible photoinhibition would have been more likely observed in May or June. Additionally, our measurements targeted healthy appearing leaves (i.e., no signs of injury or damage) and measurements of fluorescence (biochemical indicators of damage or photoinhibition) were not undertaken.
Mohammed and Parker [39] reported intermediate photosynthesis (NA) and mesophyll conductance $(\mathrm{Gm})$ rates for transferred hemlock seedlings. In our study, NA and Gm were similar and did not differ for released and sun-grown seedlings, indicating full photosynthetic acclimation to high irradiation for released beech seedlings. They also reported that pre-existing foliage in transferred hemlock seedlings underwent a prolonged decline in maximum PSII efficiency, as evidenced by measured declines in relative fluorescence for transferred seedlings. This decline seemed to be linked with sun scald injury, and restricted photoprotective capability in the preexisting foliage during the initial weeks following exposure. Photoprotection is generally viewed as an interim strategy for coping with sudden exposure to full sunlight, prior to the development of new foliage in subsequent foliar cycles $[2,18$, 26]. No measurements of fluorescence were conducted for released vs. shade-grown or sun-grown beech seedlings in this study, but would certainly have been worthwhile, particularly if measurements had been made earlier (May) in the growing season.

Nonetheless, clear signs of incomplete acclimation, as affected by structural (morphological) changes, are evident in Gs values for released seedlings in 2000 and in IWUE values for released seedlings in 2001. The similarity in photosynthesis (NA), transpiration (E), mesophyll conductance (Gm), and water use (WUE) rates for released and sun-grown beech seedlings in August 2000, confirms that functional (physiological) changes, in response to the new environment, occurred sooner than structural (morphological) changes. This is also consistent with the view that released seedlings would have limited opportunity to make structural changes in pre-existing foliage, and would need to rely primarily on physiological changes, as a primary line of defense, to cope with sudden exposure to full sunlight $[8,28,42]$.

Acknowledgements: We gratefully acknowledge the financial support of INRA and the Canadian Forest Service for this study. We thank and are especially grateful for the efforts of the following people who worked on this study: Bernard Cournault, Bruno Garnier, Eric Gerard, Florence Grandemange, Patrick Gross, Estelle Hahn, Alexandre Knepper, Francois Ningre, Emilie Parret, Michel Pitsch, Leon Wehrlen, Francois Willm. We also thank Dr. Catherine Collet (INRA, Nancy, France) and two anonymous referees for helpful reviews of the manuscript.

\section{REFERENCES}

[1] Abrams M.D., Kubiske M.E., Leaf structural characteristics of 31 hardwood and conifer tree species in central Wisconsin: influence of light regime and shade-tolerance rank, For. Ecol. Manage. 31 (1990) 245-253.

[2] Adamska I., ELIPs - light-induced stress proteins, Physiol. Plant. 100 (1997) 794-805.

[3] Aranda I., Bergasa L.F., Gil L., Pardos J.A., Effects of relative irradiance on the leaf structure of Fagus sylvatica L. seedlings planted in the understory of a Pinus sylvestris L. stand after thinning, Ann. For. Sci. 58 (2001) 673-680.

[4] Aussenac G., Interaction between forest stands and microclimate: ecophysiological aspects and consequences for silviculture, Ann. For. Sci. 57 (2000) 287-301.

[5] Aussenac G., Ducrey M., Étude bioclimatique d'une futaie feuillue (Fagus sylvatica L. et Quercus sessiliflora Salisb.) de l'Est de la 
France. 1. Analyse des profils microclimatiques et des caractéristiques anatomiques et morphologiques de l'appareil foliaire, Ann. Sci. For. 34 (1977) 265-284.

[6] Baize D., Girard M.C., A sound reference base for soils, The "referential pedologique" (in English), INRA, Paris, 1998.

[7] Bigorre F., Tessier D., Gras F., Granier A., Étude des propiétés hydriques des sols et de leur rôle dans le bilan hydrique. Application à des sols situés sur le Dogger Lorrain en forêt de Haye, Rapport Interne Agence de l'eau Rhin-Meuse/CNRS, 1996.

[8] Bazzaz F.A., Plants in Changing Environments: Linking Physiological, Population, and Community Ecology, Cambridge University Press, Cambridge, 1996.

[9] Bazzaz F.A., Carlson R.W., Photosynthetic acclimation to variability in the light environment in early and late successional plants, Oecologia 54 (1982) 313-316.

[10] Borghetti M., Leonardi S., Raschi A., Synderman D., Tognetti R., Ecotypic variation of xylem embolism, phenological traits, growth parameters and allozyme characteristics in Fagus sylvatica, Funct. Ecol. 7 (1993) 713-720.

[11] Brooks J.R., Sprugel D.G., Hinckley T.M., The effects of light acclimation during and after foliage expansion on photosynthesis of Abies amabilis foliage within the canopy, Oecologia 107 (1996) 21-32.

[12] Causton D.R., Dale M.P., The monomolecular and rectangular hyperbola as empirical models of the response of photosynthetic rate to photon flux density, with applications to three Veronica species, Ann. Bot. 65 (1990) 389-394.

[13] Coll L., Balandier P., Picon-Cochard C., Prévosto B., Curt T., Competition for water between beech seedlings and surrounding vegetation in different light and vegetation composition conditions, Ann. For. Sci. 60 (2003) 593-600.

[14] Collet C., Lanter O., Pardos M., Effects of canopy opening on height and diameter growth in naturally regenerated beech seedlings, Ann. For. Sci. 58 (2001) 127-134.

[15] Collet C., Lanter O., Pardos M., Effects of canopy opening on the morphology and anatomy of naturally regenerated beech seedlings, Trees 16 (2002) 291-298.

[16] Coutts M.P., Developmental processes in tree root systems, Can. J. For. Res. 17 (1987) 761-767.

[17] Cochard H., Lemoine D., Dreyer E., The effects of acclimation to sunlight on the xylem vulnerability to embolism in Fagus sylvatica L., Plant Cell Environ. 22 (1999) 101-108.

[18] Demmig-Adams B., Adams W.W., Grace S.C., Physiology of light tolerance in plants, Hortic. Rev. 18 (1997) 215-246.

[19] Donnelly D.J., Vidaver W.E., Pigment content and gas exchange of red raspberry in vitro and ex vitro, J. Am. Soc. Hortic. Sci. 109 (1984) 177-181.

[20] Donnelly D.J., Vidaver W.E., Colbow K., Fixation of ${ }^{14} \mathrm{CO}_{2}$ in tissue-cultured red raspberry prior to and after transfer to soil, Plant Cell Tissue Organ Cult. 3 (1984) 313-317.

[21] Emborg J., Understorey light conditions and regeneration with respect to the structural dynamics of a near-natural deciduous forest in Denmark, For. Ecol. Manage. 106 (1998) 83-95.

[22] Farquhar G.D., Richards R.A., Isotopic composition of plant carbon correlates with water-use efficiency of wheat genotypes, Aust. J. Plant Physiol. 11 (1984) 539-552.

[23] Farquhar G.D., Ehleringer J.R., Hubick K.T., Carbon isotope discrimination and photosynthesis, Annu. Rev. Plant Physiol. Plant Mol. Biol. 40 (1989) 503-537.

[24] Frochot H., Ningre F., Wehrlen L., Bernier F., Pitsch M., Garnier B., Dispositif en foret de Haye: interaction eclairement et vigueur, INRA, Nancy, 1999.

[25] Gansert D., Sprick W., Storage and mobilization of non-structural carbohydrates and biomass development of beech seedlings (Fagus sylvatica L.) under different light regimes, Trees 12 (1998) 247257.

[26] Gillies S.L., Vidaver W., Resistance to photodamage in evergreen conifers, Physiol. Plant. 80 (1990) 148-153.
[27] Gnojek A.R., Changes in chlorophyll fluorescence and chlorophyll content in suppressed Norway spruce [Picea abies (L.) Karst.] in response to release cutting, Trees 6 (1992) 41-47.

[28] Haunte P., Rincon E., Responses to light changes in tropical deciduous woody seedlings with contrasting growth rates, Oecologia 113 (1998) 53-66.

[29] Hough A.F., Silvicultural characteristics of eastern hemlock, USDA Forest Service Northeastern Forest Experiment Station Paper No. 132, Upper Darby, Pa.

[30] Johnson J.D., Tognetti R., Michelozzi M., Pinzauti S., Minotta G. Borghetti M., Ecophysiological responses of Fagus sylvatica seedlings to changing light conditions. II. The interaction of light environment and soil fertility on seedling physiology, Physiol. Plant 101 (1997) 124-134.

[31] Karakatsoulis J., Kimmins J.P., Bigley R.E., Comparison of the effects of chemical (glyphosate) and manual conifer release on conifer seedling physiology and growth on Vedder Mountain, British Columbia, in: Reynolds P.E. (Ed.), Proceedings of the Carnation Creek Herbicide Workshop, FRDA Report 063, B.C. Ministry of Forests, Victoria, B.C., 1989, pp. 168-188.

[32] Kneeshaw D.D., Williams H., Nikinmaa E., Messier C., Patterns of above- and below-ground response of understory conifer release 6 years after partial cutting, Can. J. For. Res. 32 (2002) 255-265.

[33] Larcher W., Physiological Plant Ecology, Springer-Verlag, New York, 1980.

[34] Leiffers V.J., Mugasha A.G., MacDonald S.E., Ecophysiology of shade needles of Picea glauca saplings in relation to removal of competing hardwoods and degree of prior shading, Tree Physiol. 12 (1993) 271-280.

[35] Leverenz J.W., Photosynthesis and transpiration in large forestgrown Douglas-fir: diurnal variation, Can. J. Bot. 59 (1981) 349356.

[36] Lopushinsky W., Stomatal control in conifer seedlings in response to leaf moisture status, Bot. Gaz. 134 (1969) 258-263.

[37] Madsen P., Growth and survival of Fagus sylvatica seedlings in relation to light intensity and soil water content, Scand. J. For. Res. 9 (1994) 316-322.

[38] Madsen P., Larsen J.B., Natural regeneration of beech (Fagus sylvatica $\mathrm{L}$.) with respect to canopy density, soil moisture and soil carbon content, For. Ecol. Manage. 97 (1997) 95-105.

[39] Mohammed G.H., Parker W.C., Photosynthetic acclimation in eastern hemlock [Tsuga canadensis (L.) Carr.] seedlings following transfer of shade-grown seedlings to high light, Trees 13 (1999) $117-124$.

[40] Nambiar E.K.S., Sands R., Competition for water and nutrients in forests. Can. J. For. Res. 23 (1993) 1955-1968.

[41] Ningre F., Frochot H., La Fourchaison de hêtre, état des recherches en cours vers une explication et vers la définition de stratégies sylvicoles dans la conduite des peuplements, Actes du forum de la Région Lorraine, ONF Nancy, 19 décembre 1995, pp. 103-112.

[42] Pearcy R.W., Sims D.A., Photosynthetic acclimation to changing light environments: scaling from the leaf to the whole plant, in Caldwell M.M., Pearcy R.W. (Eds.), Exploitation of Environmental Heterogeneity by Plants, Academic Press, San Diego, 1994, pp. $145-174$.

[43] Powers R.F., Ferrell G.T., Moisture, nutrient, and insect constraints on plantation growth: the "Garden of Eden" study, N.Z. J. For. Sci. 26 (1996) 126-144.

[44] Powers R.F., Reynolds P.E., Ten-year responses of ponderosa pine plantations to repeated vegetation and nutrient control along an environmental gradient, Can. J. For. Res. 29 (1999) 1027-1038.

[45] Reynolds P.E., Powers R.F., Gas exchange for managed ponderosa pine stands positioned along a climatic gradient, J. Sust. For. 10 (2000) 257-265.

[46] Reynolds P.E., Bell F.W., Simpson J.A., Lautenschlager R.A., Gordon A.M., Gresch D.A., Buckley D.A., Alternative conifer release treatments affect competition levels, available light, net assimilation rates, and growth of white spruce seedlings, J. Sust. For. 10 (2000) 277-286. 
[47] Smith M.A.L., Palta J.P., McCown B.H., Comparative anatomy and physiology of microcultured, seedling, and greenhouse-grown Asian white birch, J. Am. Soc. Hortic. Sci. 111 (1986) 437-442.

[48] Snedecor G.W., Cochran W.G., Statistical Methods, The Iowa State University Press, Ames, Iowa, 1967.

[49] Tognetti R., Johnson J.D., Michelozzi M., Ecophysiological responses of Fagus sylvatica seedlings to changing light conditions. I. Interactions between photosynthetic acclimation and photoinhibition during simulated canopy gap formation, Physiol. Plant 101 (1997) 115-123.

[50] Tognetti R., Michelozzi M., Borghetti M., Response to light of shade-grown beech seedlings subjected to different watering regimes, Tree Physiol. 14 (1994) 751-758.
[51] Van Hees A.F.M., Growth and morphology of pedunculated oak (Quercus robur L.) and beech (Fagus sylvatica L.) seedlings in relation to shading and drought, Ann. Sci. For. 54 (1997) 9-18.

[52] Watt A.S., On the ecology of British beechwoods with special reference to their regeneration, Ecology 11 (1923) 1-48.

[53] Welander T., Ottosson B., Influence of photosynthetic photon flux density on growth and transpiration in seedlings of Fagus sylvatica, Tree Physiol. 17 (1997) 133-140.

[54] Welander T., Ottosson B., The influence of shading on growth and morphology in seedlings of Quercus robur L. and Fagus sylvatica L., For. Ecol. Manage. 107 (1998) 117-126.

[55] Zhang S., Hennessey T.C., Heinemann R.A., Acclimation of loblolly pine (Pinus taeda) foliage to light intensity as related to nitrogen availability, Can. J. For. Res. 27 (1997) 1032-1040. 